\title{
Pseudomonas savastanoi and Other Bacteria Colonizing the Surface of Olive Leaves in the Field
}

\author{
By G. L. ER COLAN I \\ Istituto di Microbiologia Agraria e Tecnica, \\ Università degli Studi di Bari, Facoltà di Agraria, 70126 Bari, Italy
}

(Received 30 June 1978)

\begin{abstract}
Aerobic, heterotrophic, mesophilic bacteria were isolated from olive leaves in January, April, July and October in each of three consecutive years. Phenetic data on the isolates and marker strains were collected and analysed using numerical taxonomic methods: 1744 of the 1789 isolates were recovered in phena that were equated with Pseudomonas savastanoi (67.86\% of the isolates), Erwinia herbicola ( $8.50 \%)$, Bacillus megaterium (4.02\%), Micrococcus luteus (3.63\%), the Xanthomonas campestris group (3.35\%), Arthrobacter globiformis $(2.07 \%)$, Lactobacillus plantarum $(1.45 \%)$, Klebsiella pneumoniae $(1.40 \%)$, Serratia marcescens $(1.34 \%)$, Acetobacter aceti $(1.23 \%)$, Leuconostoc dextranicum $(1 \cdot 12 \%)$, Pseudomonas fluorescens $(1.06 \%)$, Bacillus subtilis $(0.34 \%)$ and Pseudomonas delafieldii $(0.11 \%)$. There were characteristic seasonal fluctuations in the populations of most of the bacteria. The abundance of $P$. savastanoi on healthy leaves in April and October supports earlier suggestions that the phylloplane of the host may be an important source of readily available inoculum in the epidemiology of olive knot disease.
\end{abstract}

\section{INTRODUCTION}

Pseudomonas savastanoi (Dye et al., 1975) causes the endemic disease olive knot or tubercle, which occurs in most regions of the world where Olea europaea (olive) is grown. The disease gets its name from the woody outgrowths that are most frequently found on young stems and on branches and twigs where they originate as wound infections (Smith, 1920). The organism causes a similar disease on other plants, including Fraxinus excelsior (ash), Nerium oleander (oleander) and Ligustrum japonicum (Japanese privet).

In south-east Italy, where the olive is grown extensively, the incidence and intensity of the disease increase markedly following damage to plants, especially by freezing (Ciccarone, 1964), during the spring and autumn when the cambium is active (Armenise, 1950). These observations suggest that the factors determining the prevalence of the disease may include seasonal variation in the size of the minimal effective dose, the amount of available inoculum and the extent and time of wounding. Ercolani (1971) found that the number of $P$. savastano $i$ isolates from washings of symptomless leaves, collected at three locations in south-east Italy in 1969, was not correlated with the severity of the disease in individual plants but was greater in April and November (mean $7.9 \times 10^{4}$ and $2.3 \times 10^{4}$ viable cells $\mathrm{cm}^{-2}$, respectively) than in January and August $\left(6.6 \times 10^{3}\right.$ and $5.8 \times 10^{2}$ viable cells $\mathrm{cm}^{-2}$, respectively). These results, obtained using a partially selective medium for $P$. savastano $i$, suggest that $P$. savastano $i$ populations on olive leaves may be an important source of readily available inoculum in the spring and autumn but they throw little light on the ecological relationships of $P$. savastanoi in the phylloplane microflora at different times of the year. It is, therefore, difficult to determine the relative significance of the healthy plant, the diseased tissue, the epiphytic microflora and the weather in determining the size of $P$. savastano $i$ populations available for infection. 
Table 1. Meteorological data recorded at sampling site

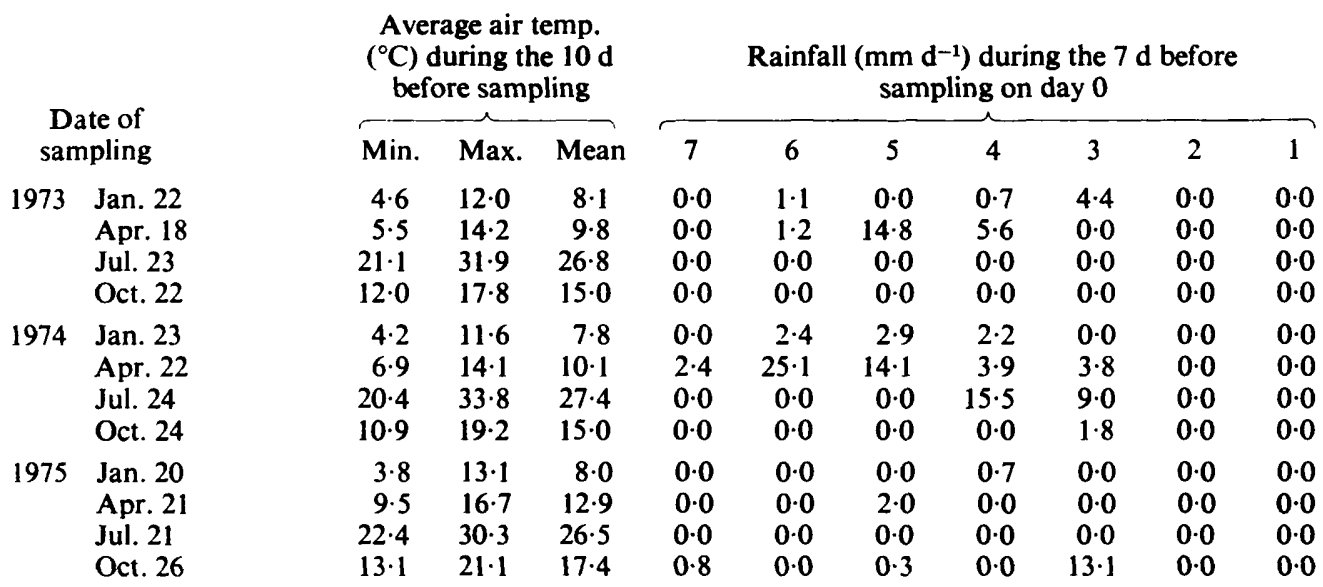

The primary aim of the present work was to follow the seasonal fluctuations in bacterial populations on the phylloplane of olive using an isolation procedure designed to select aerobic, heterotrophic, mesophilic bacteria.

\section{METHODS}

Sampling and isolation procedures. A group of 10 trees, centrally located in an olive grove, cv. Coratina, at Bitonto, Bari, Italy, was sampled quarterly from January 1973 to October 1975. Meteorological data were also recorded during this period (Table 1). On each sampling occasion, 10 clean healthy leaves were collected from each of four branches on each tree, bulked and taken immediately to the laboratory. Four random batches of leaves with a surface area of $1500 \mathrm{~cm}^{2}$ (adaxial plus abaxial), determined with a type AAM-5 area meter (Hayashi Denko, Tokyo, Japan), were washed separately in 1.51 of 4 -strength Ringer solution in a 31 flask on a reciprocal shaker (200 strokes of $\left.3 \mathrm{~cm} \mathrm{~min}^{-1}\right)$ in the dark for $2 \mathrm{~h}$ at room temperature. Controls (Crosse, 1959), using yeast tryptone glucose extract agar [YTGEA: Difco tryptone glucose extract agar, $2.4 \%(w / v)$; Difco yeast extract, $0.1 \%(w / v) ;$ glucose, $0.4 \%(w / v)]$ supplemented with $67 \mu$ g cycloheximide $\mathrm{ml}^{-1}$ as the plating medium, indicated that over $90 \%$ of the phylloplane bacteria passed into suspension and that there was no error due to bacteria multiplying in the washing fluid. These findings were supported by plating 10-fold serial dilutions of homogenates of washed and unwashed leaves on the same medium as above. There was also evidence that virtually no bacteria passed into suspension from inside the leaves (Ercolani, 1976). Cycloheximide did not significantly affect the recovery of $P$. savastanoi and Erwinia herbicola from the leaves but its effect on other bacterial taxa could not be determined as fungal contamination impaired the precision of the controls.

After washing, $1.0 \mathrm{ml}$ samples of a $10^{-3}$ dilution, pooled from the supernatant liquid, were pipetted into three Petri dishes and $12 \mathrm{ml}$ of molten $\left(48^{\circ} \mathrm{C}\right)$ YTGEA plus cycloheximide was added to each. The poured plates were surface-dried at $38{ }^{\circ} \mathrm{C}$ for approximately $30 \mathrm{~min}$ and then incubated at $28^{\circ} \mathrm{C}$ for $5 \mathrm{~d}$. Colonies visible to the naked eye were purified by streaking twice on YTGEA and incubating the plates at $28^{\circ} \mathrm{C}$. Isolates obtained at the four sampling times during the first, second and third years of work were designated collectively as sets $1: 1$ to $1: 4,2: 1$ to $2: 4$ and $3: 1$ to $3: 4$, respectively. Altogether, there were 1789 isolates: 70 in set $1: 1,346$ in $1: 2,56$ in $1: 3,104$ in $1: 4,72$ in $2: 1,281$ in $2: 2,68$ in $2: 3,130$ in $2: 4,59$ in $3: 1,418$ in $3: 2,73$ in $3: 3$ and 112 in $3: 4$.

The isolates were examined with the reference cultures listed in Table 2. Cultures $\mathrm{R} 1$ to $\mathrm{R} 6$ were included in the study from the beginning; they represented phylloplane bacteria encountered most frequently in preliminary isolation trials in several olive groves in October 1972. Additional reference cultures were added later to represent bacterial taxa identified during the present study.

Characterization of bacterial isolates. As soon as all of the isolates from a set had been purified, they were screened, together with reference cultures $\mathrm{R} 1$ to $\mathrm{R} 6$, for the 210 phenotypic characters listed in Table 3 . Characters 1 to 58,61 to 105,145 to 163,165 to $176,180,182,185$ to 188,190 to 195,199 to $201,203,204$ and 206 to 208 were determined according to Colwell \& Wiebe (1970) with a number of modifications. Thus, 
Table 2. Reference cultures

$\quad$ Taxon
Acetobacter aceti
Arthrobacter globiformis
Bacillus megaterium
Bacillus subtilis
Erwinia herbicola
Flavobacterium capsulatum
Klebsiella pneumoniae
Lactobacillus plantarum
Leuconostoc dextranicum
Micrococcus luteus
Pseudomonas delafieldii
Pseudomonas fluorescens
Pseudomonas savastanoi
Serratia marcescens
Xanthomonas campestris

Culture source/no.

NCIB 8621

ATCC 8010

ATCC 14581

ATCC 6051

ATCC 12287

ATCC 14666

ATCC 13883

ATCC 14917

ATCC 19255

ATCC 4698

ATCC 17505

ATCC 13525

NCPPB 2327

ATCC 13880

NCPPB 528

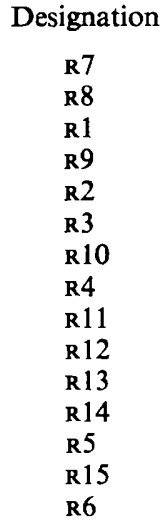

sodium chloride was omitted from basal media; both square and round cell ends were recorded as blunt ends; luminosity was not determined; and the results of tests with antibiotics were scored in terms of resistance rather than sensitivity.

In the tests for consistency of colonies, mucous and butyrous growth were recorded after $4 \mathrm{~d}$ on nutrient agar containing sucrose $(5 \%, \mathrm{w} / \mathrm{v})$. The abilities of isolates to grow in nutrient broth containing sodium chloride $(2,5$ and $10 \%, \mathrm{w} / \mathrm{v})$, nutrient agar containing crystal violet $\left(4 \mu \mathrm{g} \mathrm{ml}^{-1}\right)$, azide dextrose broth (Difco) and lauryl tryptose broth (Difco) were recorded after $7 \mathrm{~d}$. The utilization of substrates as sole carbon and energy sources was determined using the basal medium and method of Stanier et al. (1966). Phenylalanine deaminase was detected according to Ewing (1962). The hydrolysis of aesculin and arbutin was tested in liquid (Sneath, 1956) and solid (Crosse \& Garrett, 1963) media, respectively. Haemolysis was observed after $3 \mathrm{~d}$ on nutrient agar containing sodium chloride $(0.85 \%, \mathrm{w} / \mathrm{v})$ and defibrinated horse blood $(5 \%, \mathrm{v} / \mathrm{v})$. The degradation of pectate and cellulose were determined on modified pectate medium (Cuppels \& Kelman, 1974) after $3 \mathrm{~d}$ and on cellulose mineral salts medium (Skerman, 1967) after $30 \mathrm{~d}$, respectively. Heart infusion agar (Difco) containing egg yolk emulsion (10\%, v/v; Oxoid) was used for determining degradation of lecithin after $5 \mathrm{~d}$, and urea agar (Difco) for detecting urea decomposition after $2 \mathrm{~d}$. The tests for gluconate oxidation and tetrazolium reduction were performed according to Haynes (1951) and Whittenbury (1965), respectively. Soft rotting of potato slices (Lelliott et al., 1966) and induction of a hypersensitive reaction (HR) in tobacco leaves (Klement, 1963) were recorded after $2 \mathrm{~d}$.

All tests were done at $28^{\circ} \mathrm{C}$ and the results were coded on standard IBM cards in the ' 0 ' (negative), ' 1 ' (positive) format for analysis using an IBM 370/125 computer.

Computer analysis and identification of clusters. The following procedure, derived from Oliver \& Colwell (1974), was used for comparing the isolates within and between sets and for identifying the clusters.

(i) The data were analysed using the Jaccard coefficient $\left(S_{J}\right.$; Sneath, 1957) and sorted similarity matrices were obtained for each set using single linkage cluster analysis (Sokal \& Sneath, 1963). Clusters formed at or above the $70 \%$ similarity level (S level) were assigned progressive arabic numerals within each set.

(ii) The mean similarity values within and between clusters defined under (i) were calculated.

(iii) A hypothetical median organism (HMO) was generated for each cluster by comparing the phenotypic data of all isolates within the cluster and coding the HMO ' 0 ', ' 1 ' and ' 3 ' for those characters that were shared by 0 to 33,67 to 100 and 34 to $66 \%$ of the isolates in the cluster, respectively. The HMOs were assigned identification numbers corresponding to the set and cluster number from which they were derived, and their phenotypic data were entered in an $n \times t$ table as before, except that characters coded ' 3 ' were ignored and consequently the number of coded characters involved in making comparisons ranged from 171 to 210 . The data were analysed using the $S_{J}$ coefficient and the single linkage cluster analysis technique. Clusters of HMOs formed at or above the $70 \% \mathrm{~S}$ level were defined, and the mean similarity values within and between clusters were calculated as before. For each of the clusters containing HMOs a bar graph was prepared with the HMO identification number as the abscissa and the number of isolates in the cluster from which each HMO was generated as the ordinate.

(iv) Isolates previously assigned to clusters within the sets were rearranged into aggregate clusters which were given a progressive roman numeral and delimited to include only those isolates that had generated HMOs belonging to the same cluster. Within each aggregate cluster, the isolate with the highest average $S$ value with the HMOs generated from that aggregate was selected as the type isolate. Type isolates were 
Table 3. Characters examined*

Morphology and staining

1 to 5 . Length

6 to 9 . Width

10 to $19 . \quad$ Shape

20 to 24. Endospore formation

25 to 27. Gram stain

28 to 33 . Flagella and motility

34 to 35 . Inclusions

36 to 43 . Cell arrangement

Colonial characteristics

44 to $46 . \quad$ Size

47 to 50 . Elevation

51 to 55 . Edge

56 to 58 . Density

59 to 60 . Consistency

61 to 76 . Pigment formation

Growth in broth

77 to 83 . Type of growth

84 to 94 . Temperature range

95 to 105 . pH range

106 to 108 . Osmotic range

Sole carbon sources

109. Arabinose

$110 . \quad$ Ribose

111. Xylose

112. Fructose

113. Galactose

114. Glucose

115. Mannose

116. Lactose

117. Sucrose

118. Raffinose

119. Methyl $\alpha$-D-glucoside

120. Methyl $\beta$-D-glucoside

121. Ethanol

122. Glycerol

123. Mannitol

124. meso-Inositol

125. Sodium acetate

126. Sodium $p$-hydroxybenzoate

127. Sodium citrate

128. Sodium formate

129. Sodium fumarate

130. Sodium 2-ketogluconate

131. Sodium 2-ketoglutarate

132. Sodium DL-lactate

133. Sodium D(+)-malate

134. Sodium maleate

135. Sodium malonate

136. Sodium oxalate

137. Sodium propionate

138. Sodium succinate

139. Sodium D-tartrate

140. Sodium L-tartrate

141. DL- $\alpha$-Alanine

142. L-Glutamic acid

143. DL-Methionine

$144 . \quad$ L-Proline
Mode of utilization of carbon sources

145 to 148 . Glucose, oxidation-fermentation

149 to 150 . Ribose, acid/gas from

151 to 152 . Galactose, acid/gas from

153 to 154 . Lactose, acid/gas from

155 to 156. Sucrose, acid/gas from

157 to 158 . Salicin, acid/gas from

159 to 160 . Mannitol, acid/gas from

Nitrogen metabolism

161. Arginine dihydrolase

162. Lysine decarboxylase

163. Ornithine decarboxylase

164. Phenylalanine deaminase

165. Peptone, $\mathrm{NH}_{3}$ from

166 to 174. Growth on media $a$ to $i$

175 to 176. Nitrate, nitrite/gas from

Degradation of miscellaneous substrates

177. Aesculin

178. Arbutin

$179 . \quad$ Blood

180. Casein

181. Cellulose

182. Gelatin

183. Lecithin

184. Pectate

185. Starch

186. Tween 20

187. Tween 40

188. Tween 80

$189 . \quad$ Urea

Antibiotic resistance

190. Chloromycetin, $30 \mu \mathrm{g}$

191. Colimycin, $10 \mu \mathrm{g}$

192. Dihydrostreptomycin, $10 \mu \mathrm{g}$

193. Oleandomycin, $15 \mu \mathrm{g}$

194. Penicillin, 10 units

195. Tetracycline, $30 \mu \mathrm{g}$

Tolerance to selective agents

196. Crystal violet

197. Sodium azide

198. Sodium lauryl sulphate

Miscellaneous characters

$199 . \quad$ Catalase activity

200. Oxidase activity

201. Phosphatase activity

202. Gluconate oxidation

203. Acetoin production

204. Methyl red, acid colour

205. Tetrazolium reduction

206. Indole production

207. Cysteine. $\mathrm{HCl}, \mathrm{H}_{2} \mathrm{~S}$ from

208. Sodium thiosulphate, $\mathrm{H}_{2} \mathrm{~S}$ from

$209 . \quad$ Potato soft rot

210. Hypersensitivity in tobacco

* For details of tests, see Methods. 


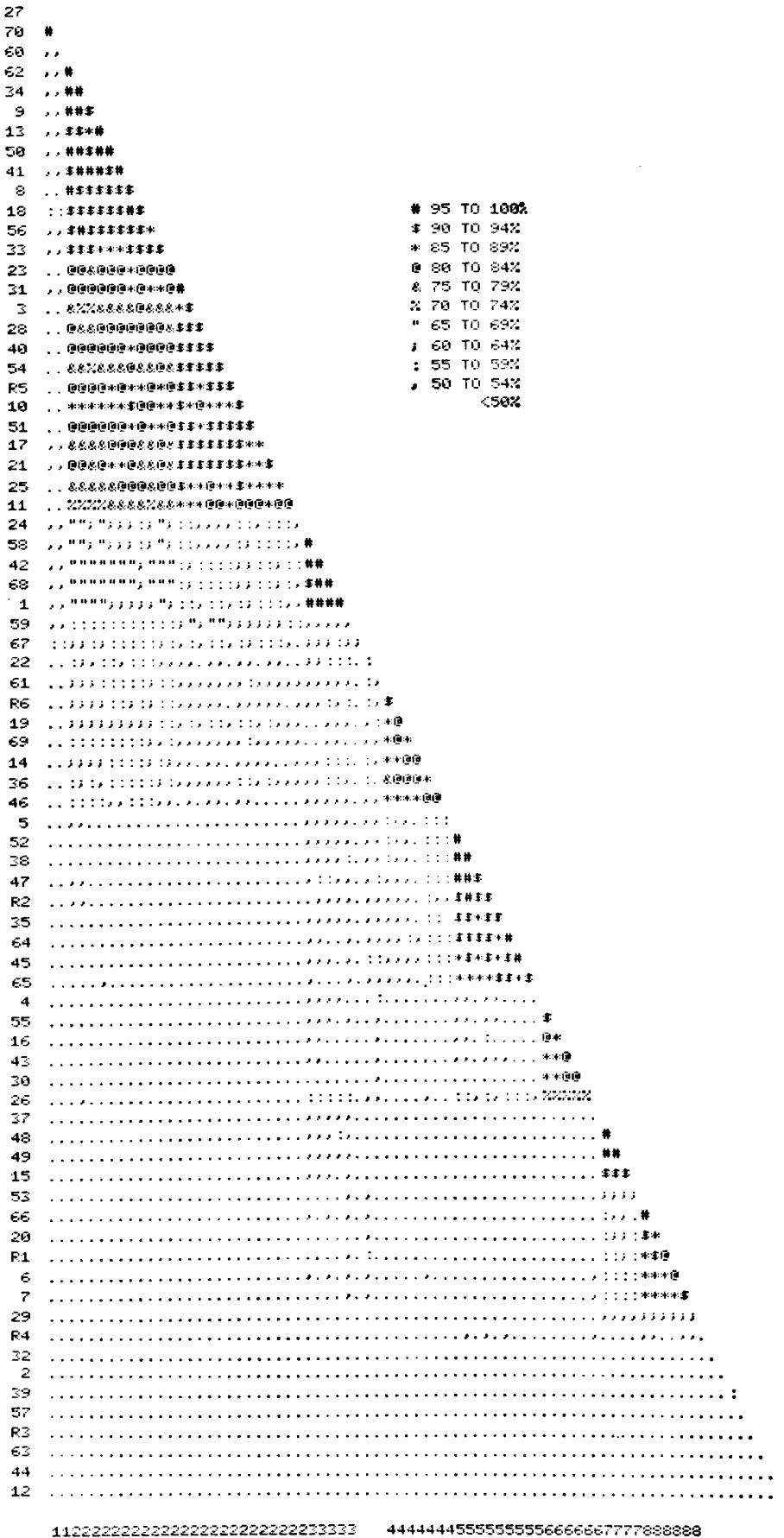

Fig. 1. Computer-produced similarity matrix based on the $S_{J}$ coefficient and single linkage cluster analysis for the isolates in set 1:1 including the reference cultures R1 to R6. The numbers of the defined clusters are given at the bottom of the matrix. 
Table 4. Distribution and identification of isolates from olive leaves

\begin{tabular}{|c|c|c|c|c|}
\hline $\begin{array}{c}\text { Set and } \\
\text { cluster no.* }\end{array}$ & $\begin{array}{l}\text { No. of } \\
\text { isolates in } \\
\text { cluster }\end{array}$ & $\begin{array}{l}\text { Aggregate } \\
\text { cluster no.† }\end{array}$ & $\begin{array}{l}\text { Identification of type isolate in } \\
\text { aggregate cluster and its } \% \mathrm{~S} \text { range } \\
\text { with other isolates in the cluster }\end{array}$ & $\begin{array}{l}\text { Reference culture } \neq \\
\text { and } \% \mathrm{~S} \text { range with } \\
\text { isolates in the cluster }\end{array}$ \\
\hline $1: 1,1$ & 2 & I & Pseudomonas delafieldii (100) & R13 (79) \\
\hline $1: 1,2$ & 23 & II & Pseudomonas savastanoi (77-97) & R5 (81-94) \\
\hline $1: 1,3$ & 5 & III & Pseudomonas fluorescens (93-98) & R14 (83-88) \\
\hline $1: 1,4$ & 6 & IV & Xanthomonas campestris group (80-89) & R6 (80-90) \\
\hline $1: 1,5$ & 8 & V & Erwinia herbicola (89-98) & R2 (88-95) \\
\hline $1: 1,6$ & 5 & VI & Klebsiella pneumoniae (85-92) & R10 (80-88) \\
\hline $1: 1,7$ & 4 & VII & Bacillus subtilis (92-99) & R9 (75-84) \\
\hline $1: 1,8$ & 5 & VIII & Bacillus megaterium (86-95) & R1 (83-91) \\
\hline $1: 2,1$ & 330 & II & P. savastanoi $(76-100)$ & R5 (80-92) \\
\hline $1: 2,2$ & 5 & V & E. herbicola (88-98) & R2 (87-96) \\
\hline $1: 2,3$ & 8 & VIII & B. megaterium (82-98) & R1 (82-89) \\
\hline $1: 2,4$ & 3 & IX & Micrococcus luteus (93-99) & R12 (78-86) \\
\hline $1: 3,1$ & 2 & II & P. savastanoi (99) & R5 (83-84) \\
\hline $1: 3,2$ & 8 & IV & $X$. campestris group (79-90) & R6 (76-88) \\
\hline $1: 3,3$ & 6 & V & E. herbicola (84-97) & R2 (83-95) \\
\hline $1: 3,4$ & 8 & $\mathbf{X}$ & Serratia marcescens (86-98) & R15 (80-83) \\
\hline $1: 3,5$ & 7 & VIII & B. megaterium (81-96) & R1 (84-95) \\
\hline $1: 3,6$ & 4 & XI & Leuconostoc dextranicum (89-98) & R11 (80-91) \\
\hline $1: 3,7$ & 2 & XII & Lactobacillus planturum (98) & R4 (82-84) \\
\hline $1: 3,8$ & 4 & XIII & Arthrobacter globiformis (94-99) & R8 (80-83) \\
\hline $1: 3,9$ & 13 & IX & M. luteus (86-98) & R $12(78-94)$ \\
\hline $1: 4,1$ & 48 & II & P. savastanoi (79-97) & R5 (79-87) \\
\hline $1: 4,2$ & 8 & IV & $X$. campestris group (80-92) & R6 (75-84) \\
\hline $1: 4,3$ & 3 & XIV & Acetobacter aceti (96-98) & R7 (84-96) \\
\hline $1: 4,4$ & 26 & V & E. herbicola $(81-100)$ & R2 (76-92) \\
\hline $1: 4,5$ & 2 & VIII & B. megaterium (96) & R1 (81-83) \\
\hline $1: 4,6$ & 6 & XII & La. plantarum (82-97) & R4 (80-90) \\
\hline $1: 4,7$ & 8 & XIII & Ar. globiformis $(96-100)$ & R8 (76-89) \\
\hline $1: 4,8$ & 2 & IX & M. luteus $(100)$ & R12 (76) \\
\hline $2: 1,1$ & 15 & II & P. savastanoi $(80-98)$ & R5 (81-93) \\
\hline $2: 1,2$ & 7 & III & P. fluorescens (94-98) & R/4 (81-90) \\
\hline $2: 1,3$ & 9 & IV & $X$. campestris group $(80-91)$ & R6 (78-90) \\
\hline $2: 1,4$ & 12 & V & E. herbicola (85-100) & R2 (80-94) \\
\hline $2: 1,5$ & 10 & VI & K. pneumoniae (85-96) & R10 (76-85) \\
\hline $2: 1,6$ & 7 & VIII & B. megaterium (83-100) & R1 (81-90) \\
\hline $2: 1,7$ & 3 & IX & M. luteus $(97-100)$ & $\mathrm{R} 12(78-90)$ \\
\hline $2: 2,1$ & 262 & II & P. savastanoi $(77-100)$ & R5 (81-90) \\
\hline $2: 2,2$ & 6 & V & E. herbicola (88-94) & R2 (82-95) \\
\hline $2: 2,3$ & 9 & VIII & B. megaterium (79-98) & R1 (76-90) \\
\hline $2: 2,4$ & 4 & IX & M. Iuteus (91-97) & R12 (78-88) \\
\hline $2: 3,1$ & 4 & II & P. savastanoi (88-96) & R5 (77--94) \\
\hline $2: 3,2$ & 9 & IV & $X$. campestris group (78-95) & R6 (76-89) \\
\hline $2: 3,3$ & 7 & V & E. herbicola (96-98) & R2 (83-91) \\
\hline $2: 3,4$ & 6 & $\mathbf{X}$ & S. marcescens (88-97) & R15 (79-86) \\
\hline $2: 3,5$ & 11 & VIII & B. m ?gaterium (82-99) & R1 (78-91) \\
\hline $2: 3,6$ & 4 & XI & Le. dextranicum $(88-100)$ & R11 (78-84) \\
\hline $2: 3,7$ & 6 & XII & La. plantarum (84-96) & R4 (78-89) \\
\hline $2: 3,8$ & 3 & XIII & Ar. globiformis (97-99) & R8 (78-85) \\
\hline $2: 3,9$ & 15 & IX & M. luteus $(84-100)$ & $\mathbf{R} 12(75-91)$ \\
\hline $2: 4,1$ & 62 & II & P. savastanoi $(78-100)$ & R5 (80-92) \\
\hline $2: 4,2$ & 11 & XIV & Ac. aceti $(84-100)$ & R7 (80-93) \\
\hline $2: 4,3$ & 28 & V & E. herbicola $(78-100)$ & R2 (77-94) \\
\hline $2: 4,4$ & 4 & XI & Le. dextranicum (86-96) & R11 (77-89) \\
\hline $2: 4,5$ & 6 & XII & La. plantarum (85-98) & R4 (77-92) \\
\hline $2: 4,6$ & 11 & XIII & Ar. globiformis (89-97) & R8 (76-90) \\
\hline $2: 4,7$ & 3 & IX & M. luteus (92-98) & R12 (79-86) \\
\hline $3: 1,1$ & 11 & II & P. savastanoi $(80-97)$ & R5 (80-94) \\
\hline $3: 1,2$ & 7 & III & P. fluorescens (95-99) & R14 (79-87) \\
\hline $3: 1,3$ & 4 & IV & $X$. campestris group (78-92) & R6 (78-88) \\
\hline $3: 1,4$ & 9 & V & E. herbicola $(86-100)$ & R2 $(80-97)$ \\
\hline $3: 1,5$ & 9 & VI & K. pneumoniae (86-95) & R10 $(78-84)$ \\
\hline
\end{tabular}




\section{Table 4 (cont.)}

\begin{tabular}{|c|c|c|c|c|}
\hline $\begin{array}{l}\text { Set and } \\
\text { cluster no.* }\end{array}$ & $\begin{array}{l}\text { No. of } \\
\text { isolates in } \\
\text { cluster }\end{array}$ & $\begin{array}{l}\text { Aggregate } \\
\text { cluster no. } \dagger\end{array}$ & $\begin{array}{l}\text { Identification of type isolate in } \\
\text { aggregate cluster and its \%S range } \\
\text { with other isolates in the cluster }\end{array}$ & $\begin{array}{l}\text { Reference culture } \\
\text { and \%S range wit } \\
\text { isolates in the clus }\end{array}$ \\
\hline $3: 1,6$ & 2 & VII & B. subtilis (100) & R9 (80) \\
\hline $3: 1,7$ & 7 & VIII & B. megaterium $(83-100)$ & R1 (78-89) \\
\hline $3: 1,8$ & 2 & IX & M. luteus (100) & R12 (78) \\
\hline $3: 2,1$ & 409 & II & P. savastanoi $(76-100)$ & R5 (76-89) \\
\hline $3: 2,2$ & 4 & V & E. herbicola (92-99) & R2 (88-96) \\
\hline $3: 2,3$ & 5 & VIII & B. megaterium (84-97) & R1 (75-88) \\
\hline $3: 3,1$ & 2 & II & P. savastanoi $(100)$ & R5 (90) \\
\hline $3: 3,2$ & 11 & IV & $X$. campestris group (80-91) & R6 (75-90) \\
\hline $3: 3,3$ & 8 & $\mathbf{V}$ & E. herbicola $(89-95)$ & R2 (80-97) \\
\hline $3: 3,4$ & 10 & $\mathbf{X}$ & S. marcescens $(85-100)$ & R15 (78-89) \\
\hline $3: 3,5$ & 9 & VIII & B. megaterium (82-96) & R1 (79-88) \\
\hline $3: 3,6$ & 5 & XI & Le. dextranicum (87-96) & R11 (80-88) \\
\hline $3: 3,7$ & 4 & XII & La. plantarum (91-95) & R4 (80-92) \\
\hline $3: 3,8$ & 4 & XIII & Ar. globiformis (90-96) & R8 (81-88) \\
\hline $3: 3,9$ & 16 & IX & M. luteus (85-99) & R12 (77-93) \\
\hline $3: 4,1$ & 46 & II & P. savastanoi $(78-100)$ & R5 (80-95) \\
\hline $3: 4,2$ & 5 & IV & $X$. campestris group (80-97) & R6 (75-84) \\
\hline $3: 4,3$ & 8 & XIV & Ac. aceti (85-97) & R7 (81-92) \\
\hline $3: 4,4$ & 33 & V & E. herbicola (77-99) & R2 (75-97) \\
\hline $3: 4,5$ & 2 & VIII & B. m?gaterium (99) & R1 (83-84) \\
\hline $3: 4,6$ & 3 & XI & Le. dextranicum (92-99) & R11 (86-92) \\
\hline $3: 4,7$ & 2 & XII & La. plantarum (94) & R4 (77-82) \\
\hline $3: 4,8$ & 7 & XIII & Ar. globiformis (88-98) & R8 (80-91) \\
\hline $3: 4,9$ & 4 & IX & M. luteus (88-97) & R12 (81-91) \\
\hline
\end{tabular}

* Sets $1: 1$ to $1: 4,2: 1$ to $2: 4$ and $3: 1$ to $3: 4$ contained the isolates obtained in January, April, July and October during the first, second and third years of study, respectively.

$\dagger$ Each aggregate cluster included the isolates from clusters that generated hypothetical median organisms (Oliver \& Colwell, 1974) linked at $\geqslant 70 \% \mathrm{~S}$.

¥ See Table 2.

identified to the genus level or below according to Buchanan \& Gibbons (1974), with the exception of HRpositive pseudomonads that were identified to the species level according to Sands et al. (1970).

In the sequence described above the first step determined the existence and size of clusters of phenetically highly related isolates within each set, steps (ii) and (iii) determined the quantitative variations of different phenetic groups in time and step (iv) identified the isolates representative of the defined phenetic groups.

In control experiments performed at the end of the work described above, the reference cultures R7 to R15 were characterized as before. From these, and the data for $\mathrm{R} 1, \mathbf{R} 2, \mathbf{R} 4, \mathrm{R} 5$ and $\mathrm{R} 6$, the $S_{J}$ value was calculated for each of the pair comparisons between the isolates in each aggregate cluster and the reference culture that represented the taxon to which the type isolate of the aggregate cluster had been assigned. When all reference cultures were added to each of the seasonal sets and the sequence (i) to (iv) described above was repeated, the distribution of the isolates among the various clusters remained unchanged. The similarity matrix for the isolates in cluster $1: 1$ and the reference cultures $\mathrm{R} 1$ to $\mathrm{R} 6$ is shown in Fig. 1 .

\section{RESULTS}

The distribution of the isolates to clusters within each set is shown in columns 1 and 2 of Table 4 . Over $97 \%$ of the isolates, 1744 out of 1789 , were recovered in clusters defined at or above the $70 \% \mathrm{~S}$ level. In fact, mean intracluster and intercluster similarity values were invariably greater than $85 \%$ and smaller than $60 \%$, respectively. The three sets obtained in April were the most homogeneous. Approximately $96 \%$ of the isolates in these sets fell in one cluster, the remainder being distributed in two or three additional clusters. In contrast, the January and July sets were, with one exception, the most heterogeneous with no more than $23 \%$ of the isolates contained in any one of the seven to nine clusters defined within each set. The exception was set $1: 1$ in which approximately $33 \%$ of the isolates were recovered in a single cluster. The October sets also contained between seven and nine clusters, and the 
largest two contained, on average, approximately $70 \%$ of the isolates. The proportion of isolates that were not clustered was highest in January $(15.7 \%$ in $1973,12.5 \%$ in 1974 and $13.6 \%$ in 1975) and intermediate in July (3.6, 4.4 and $5.5 \%)$ and October $(1 \cdot 0,3 \cdot 8$ and $1.8 \%)$. In the April samples all of the isolates were recovered in defined clusters.

The isolates in the defined clusters were arranged into 14 aggregate clusters as shown in column 3 of Table 4 . Most of the aggregate clusters contained between 19 and 72 isolates but a minimum of 2 and a maximum of 1214 isolates were recorded in aggregate clusters $I$ and II, respectively. Mean similarity values $>82 \%$ and $<60 \%$ were invariably recorded within and between aggregate clusters, respectively.

The identification of the type isolate of each aggregate cluster and the range of $S$ values between the isolates in each cluster and the appropriate reference culture are shown in columns 4 and 5 of Table 4. Using these data (see Discussion) isolates in aggregate cluster IV were equated to the Xanthomonas campestris group and those in aggregate clusters I to III and V to XIV were identified as Pseudomonas delafieldii, P. savastanoi, P. fluorescens, Erwinia herbicola, Klebsiella pneumoniae, Bacillus subtilis, B. megaterium, Micrococcus luteus, Serratia marcescens, Leuconostoc dextranicum, Lactobacillus plantarum, Arthrobacter globiformis and Acetobacter aceti, respectively. These data combined with those in columns 1 to 3 of Table 4 show that the distribution of the named bacteria differed considerably among the sets obtained in the different seasons of a year, but not among those obtained during the same season in different years.

Rearrangement of the data from Table 4 shows that the average number of named isolates regularly encountered at different times of the year were: B. megaterium (6), E. herbicola (10), $K$. pneumoniae (8), $P$. fluorescens (6), $P$. savastanoi (16) and the $X$. campestris group (6) in January; B. megaterium (7), E. herbicola (5) and P. savastanoi (334) in April; Ar. globiformis (4), B. megaterium (9), E. herbicola (7), La. plantarum (4), Le. dextranicum (4), M. luteus (15), $P$. savastanoi (3), S. marcescens (8) and the X. campestris group (9) in July; and Ac. aceti (7), Ar. globiformis (9), E. herbicola (29), La. plantarum (4), M. luteus (3) and P. savastanoi (52) in October. Other isolates recovered in two of the three years were: $B$. subtilis (3) and $M$. luteus (3) in January; M. luteus (4) in April; and B. megaterium (2), Le. dextranicum (4) and the $X$. campestris group (7) in October. Gram-positive bacteria were the most common $(52.1$ to $57.4 \%)$ isolates obtained in July, fell to a minimum $(1.2$ to $4.6 \%)$ in April, and remained approximately constant in January (12.9 to $18.6 \%)$ and October (16.1 to $18.5 \%)$. Pigmented isolates, comprising aggregate clusters II, III, IV, IX, X, XIII and part of aggregate cluster $\mathrm{V}$, formed 44.1 to $51.4 \%$ of the total in January, 57.4 to $66.1 \%$ in July, 62.5 to $69.2 \%$ in October, and 95.4 to $98.1 \%$ in April.

The seasonal fluctuations in the populations of most of the named bacteria fell into recognizable patterns (Fig. 2). Thus, $P$. savastanoi and $E$. herbicola were found in all of the samples, but the former increased 14- to 37-fold from January to April, decreased to between $0.7 \times 10^{3}$ and $1.3 \times 10^{3}$ viable bacteria $\mathrm{cm}^{-2}$ in July and, in October, increased again to levels that were from two to four times as high as those in January. In contrast, the numbers of $E$. herbicola remained approximately constant in January, April and July and increased 2.33to $8 \cdot 25$-fold in October. Bacteria identified in more than half of the sets included the $X$. campestris group which always fell below the detection level in April, B. megaterium that invariably declined in October and $M$. luteus, populations of which were above average in July. Arthrobacter globiformis and La. plantarum were only regularly found in July and October, the former differing from the latter by showing higher populations in October than in July. A pattern of seasonal fluctuation similar to that of $L a$. plantarum was also exhibited by Le. dextranicum, although the latter fell below the threshold level in October 1973. Most of the remaining bacteria were consistently encountered at yearly intervals: $K$. pneumoniae and $P$. fluorescens in January, $S$. marcescens in July and Ac. acet i in October. Bacillus subtilis was only detected in January 1973 and 1975, and $P$. delafieldii in January 1973. 


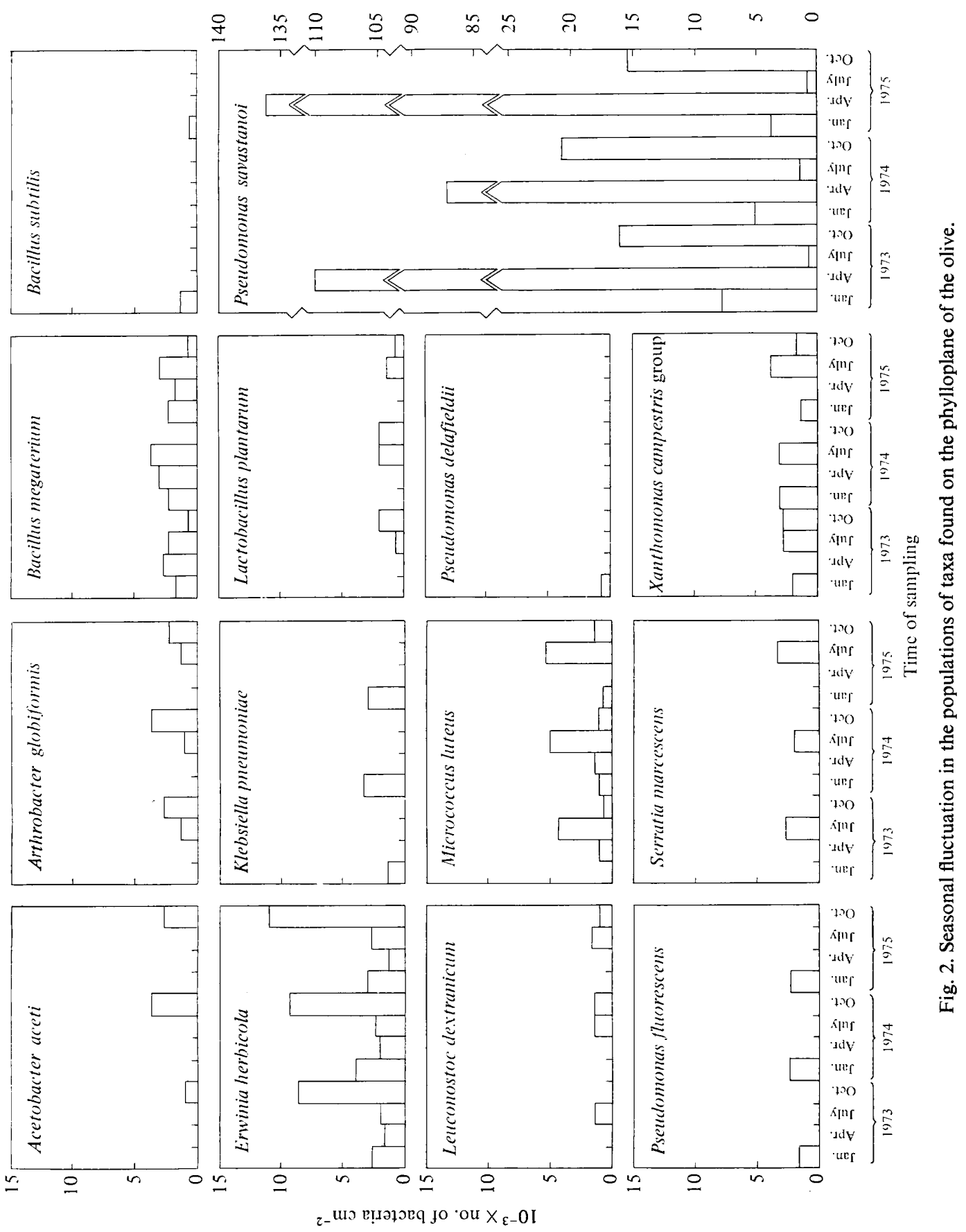




\section{DISCUSSION}

Current views on the types of bacteria to be expected on the aerial parts of plants (Billing, 1976) make it reasonable to assume that the selection procedure adopted for the isolation of the aerobic, heterotrophic, mesophilic strains should not have been biased against any major component of the bacterial community. Determination of the bacterial populations using $10^{-2}$ instead of $10^{-3}$ dilutions in January, July and October would have lowered the threshold for the detection of different bacterial types but would have resulted in an almost unmanageable number of isolates and, more importantly, the comparison between the sets obtained in April and at other times of the year would have been unbalanced.

Numerical taxonomic methods afford an effective way of monitoring variation in populations of phylloplane bacteria (Goodfellow et al., 1976; Austin et al., 1978) but they present the user with a choice of alternatives which may affect their outcome. In the present study, the $S_{J}$ coefficient, which excludes negative matches, was preferred to the simple matching coefficient $\left(S_{S M}\right.$; Sokal \& Michener, 1958), which includes both positive and negative matches, to minimize differences arising from inapplicable tests (Sneath, 1972). As the $S_{J}$ coefficient emphasizes differences between isolates (Austin \& Colwell, 1977), single linkage instead of average linkage cluster analysis was used throughout the study. The analysis was intended to find preferentially (Sneath, 1972) elongated aggregate clusters expected to include the isolates of major taxa obtained at different times of the year, but control experiments showed that it defined virtually the same clusters as the unweighted pair group method with arithmetic averages (Sneath, 1972). The analysis method chosen was easily programmed and quickly carried out on the computer. Test error and reproducibility were not monitored but statistical analysis of the 12 replicate sets of test data available for the reference cultures $\mathrm{R} 1$ to $\mathrm{R} 6$ indicated that there was an average probability of erroneous test results $(p ;$ Sneath \& Johnson, 1972) of $1.435 \%$. This, combined with the recovery of isolates in well-defined homogeneous clusters, suggests that test error remained within acceptable limits.

The numerical phenetic method used provided a continuous way of monitoring the efficiency of the approach for identifying the phylloplane bacteria and measuring their seasonal variation. Thus, mean similarity values of $>85 \%$ and $<60 \%$ within and between clusters, respectively, indicated that the clustering procedure was successful in recovering well-isolated 'species level' groupings (Colwell \& Liston, 1961; Liston et al., 1963; Colwell \& Mandel, 1964) from the seasonal sets. In addition, the formation of aggregate clusters showing mean intracluster and intercluster similarity values of the same order of magnitude suggested that the degree of inter-relatedness among the isolates in the same aggregate cluster, and the degree of their separation from other isolates, were similar to those expected within and between 'species level' groupings, respectively. The finding that all of the isolates in an aggregate cluster formed a well-defined phenon with the reference culture representing the type isolate justified naming the group after the reference culture (Skerman, 1967). A limited number of reference cultures was included in this study but the successful identification of all the phena suggested that the criterion for their choice was effective; however, the same criterion may be of limited value under different circumstances (Austin et al., 1978).

It is difficult to compare the results of the present study with earlier work on phylloplane bacteria because of differences both in methodology and the type of plant studied. However, the finding that only a few taxa were present on olive leaves at any given time of sampling was in good agreement with previous studies (Dickinson et al., 1975; Goodfellow et al., 1976; Austin et al., 1978). The frequency of pigmented isolates on leaves was also in line with earlier reports (Voznyakovskaya \& Khudyakov, 1960; Stout, 1960; Jensen, 1971; Klincāre et al., 1971; Dickinson et al., 1975; Austin et al., 1978). Arginine dihydrolasenegative fluorescent plant pathogenic pseudomonads comprise several well-recognized epiphytes (Leben, 1965, 1974; Schuster \& Coyne, 1974) and such strains, identified as $P$. savastanoi, accounted for approximately two-thirds of all the isolates obtained in the present 
survey. Despite differences in methodology, the recovery and incidence of $P$. savastanoi strains from olive leaves at different times of the year did not differ appreciably from those recorded in earlier studies (Ercolani, 1971), suggesting that the recurrent concomitance between high density of the pathogen in the phylloplane and cambial activity of the host may be responsible for the observed increase in the infection pressure of olive knot disease in the spring and autumn.

The second most frequently encountered taxon on olive leaves was $E$. herbicola which also includes plant surfaces among its natural habitats (Murata \& Starr, 1974; Billing, 1976). Less than a quarter of the olive phylloplane isolates were distributed among the following taxa with decreasing frequency: $B$. megaterium, $M$. luteus, the $X$. campestris group, Ar. globiformis, La. plantarum, K. pneumoniae, S. marcescens, Ac. aceti, Le. dextranicum, $P$. fluorescens, B. subtilis and $P$. delafieldii. Several of these taxa have been reported in previous surveys, i.e. $P$. fluorescens (Voznyakovskaya \& Khudyakov, 1960; Goodfellow et al., 1976; Austin et al., 1978), the X. campestris group (Leben, 1963; Goto, 1972; Austin et al., 1978), La. plantarum (Pederson, 1936; Voznyakovskaya \& Khudyakov, 1960), B. megaterium (Stout, 1960; Voznyakovskaya \& Khudyakov, 1960), B. subtilis (Stout, 1960) and M. luteus (Voznyakovskaya \& Khudyakov, 1960). Klebsiella pneumoniae has been reported from habitats as different as forest trees and farm produce (Duncan \& Razzell, 1972; Brown \& Seidler, 1973) but its true epiphytic nature has not been established until now. Although there appear to be no previous reports of Le. dextranicum from the phylloplane its presence on olive leaves was not surprising in view of the recognized ability of several lactic acid bacteria to colonize plant surfaces (Mundt et al., 1962; Stirling \& Whittenbury, 1963). The discontinuous occurrence of $S$. marcescens and Ac. aceti, which were only isolated from olive leaves in July and October, respectively, may explain their omission in previous surveys of the phylloplane flora.

Several factors, such as leaf age and nutrition and the source of colonizing bacteria, may influence the density of bacterial populations on olive leaves and thereby affect their seasonal fluctuation. At present it is not known whether the bacterial populations on olive leaves occur in the olive environment at large or whether they fluctuated in alternative niches at the same rate as on the phylloplane. It is also not yet possible to draw precise correlations between environmental parameters and the effectiveness of a given bacterium in colonizing the phylloplane, but the consistency in the pattern of seasonal fluctuation in bacterial populations over the three years strongly suggests that the dynamics of different bacterial populations present on the phylloplane at any given time are governed by regularly recurrent events in their habitat. The fact that isolates of $P$. savastanoi obtained at different times of the year differed in several cultural, physiological and biochemical characters also suggests that the relative efficiency of the bacteria in utilizing the leaf surface as a substrate for growth and survival may be an important factor in this respect. Material originating outside the leaf may improve the nutrient value of the phylloplane for some micro-organisms (Fokkema, 1971; Yoder \& Whalen, 1975; Clark \& Lorbeer, 1976), but a significant role for pollen on the phylloplane of the olive does not seem likely as control experiments resulted in a lower recovery of bacteria from olive leaves in May, when the olive and most grasses were flowering in the area, than in April. A similar conclusion was reached by Dickinson et al. (1975) in their study of phylloplane bacteria from Lolium perenne.

The relevance of most phylloplane bacteria in the biology of the olive has still to be determined. Klebsiella pneumoniae is able to fix nitrogen but it is unlikely that the environmental conditions for this (Pengra \& Wilson, 1958; St John et al., 1974) exist on the phylloplane of the olive. Further work is also required to determine whether the systematic occurrence of Ac. aceti, La. plantarum and Le. dextranicum on the phylloplane of the olive in October is related to their presence on the surface of ripening olive fruit at harvesting, a fact that may have significant effects on the fermentation of such fruit in the pickling industry (Cruess, 1930; Vaughn, 1954). Finally, since $P$. savastanoi does not readily infect olive 
leaves, future studies should clarify the lack of correlation between the ability to build high populations on olive leaves and what is considered a prerequisite of high virulence, i.e. multiplication in the host tissues from small inocula (Ercolani \& Crosse, 1966; Ercolani, 1973).

\section{REFERENCES}

Armenise, V. (1950). Cicli di accrescimento e differenziazione delle gemme in piante perenni nel territorio di Bari. VIII. L'accrescimento di Olea europaea L. negli anni 1948-1949. Nuovo giornale botanico italiano 57, 391-417.

Austin, B. \& Colwell, R. R. (1977). Evaluation of some coefficients for use in numerical taxonomy of microorganisms. International Journal of Systematic Bacteriology 27, 204-210.

Austin, B., Goodfellow, M. \& Dickinson, C. H. (1978). Numerical taxonomy of phylloplane bacteria isolated from Lolium perenne. Journal of General Microbiology 104, 139-155.

Billing, E. (1976). The taxonomy of bacteria on the aerial parts of plants. In Microbiology of Aerial Plant Surfaces, pp. 223-273. Edited by C. H. Dickinson and T. F. Preece. London and New York: Academic Press.

Brown, C. \& Seidler, R. J. (1973). Potential pathogens in the environment: Klebsiella pneumoniae, a taxonomic and ecological enigma. Applied Microbiology 25, 900-904.

Buchanan, R. E. \& Gibbons, N. E. (editors) (1974). Bergey's Manual of Determinative Bacteriology, 8th edn. Baltimore: Williams \& Wilkins.

Ciccarone, A. (1964). Orientamenti sui problemi patologici di maggiore interesse per il futuro dell'olivicoltura. Informatore fitopatologico 19, $430-436$.

Clark, C. A. \& Lorbeer, J. W. (1976). The development of Botrytis squamosa and B. cinerea on onion leaves as affected by exogenous nutrients and epiphytic bacteria. In Microbiology of Aerial Plant Surfaces, pp. 607-625. Edited by C. H. Dickinson and T. F. Preece. London and New York: Academic Press.

Colwell, R. R. \& Liston, J. (1961). Taxonomic relationships among the pseudomonads. Journal of Bacteriology 82, 1-14.

Colwell, R. R. \& Mandel, M. (1964). Adansonian analysis and deoxyribonucleic acid base composition of some gram-negative bacteria. Journal of Bacteriology 87, 1412-1422.

Colwell, R. R. \& Wiebe, W. J. (1970). 'Core' characteristics for use in classifying aerobic, heterotrophic bacteria by numerical taxonomy. Bulletin of the Georgia Academy of Science 28, 165-185.

Crosse, J. E. (1959). Bacterial canker of stone-fruits. IV. Investigation of a method for measuring the inoculum potential of cherry trees. Annals of Applied Biology 47, 306-317.

Crosse, J. E. \& Garrett, C. M. E. (1963). Studies on the bacteriophagy of Pseudomonas morsprunorum, Ps. syringae and related organisms. Journal of Applied Bacteriology 26, 159-177.

Cruess, W. V. (1930). Pickling green olives. Bulletin of the California Agricultural Experiment Station 498.
Cuppels, D. \& Kelman, A. (1974). Evaluation of selective media for isolation of soft-rot bacteria from soil and plant tissue. Phytopathology 64, 468-475.

Dickinson, C. H., Austin, B. \& Goodfellow, M. (1975). Quantitative and qualitative studies of phylloplane bacteria from Lolium perenne. Journal of General Microbiology 91, 157-166.

DunCAN, D. W. \& RAZzell, W. E. (1972). Klebsiella biotypes among coliforms isolated from forest environments and farm produce. Applied Microbiology 24, 933-938.

Dye, D. W., Bradbury, J. F., Dickey, R. S., Goto, M., Hale, C. N., Hayward, A. C., Kelman, A., Lelliott, R. A., Patel, P. N., SANDS, D. C., SChroth, M. N., Watson, D. R. W. \& YounG, J. M. (1975). Proposals for a reappraisal of the status of the names of plant-pathogenic Pseudomonas species. International Journal of Systematic Bacteriology 25, 252-257.

Ercolani, G. L. (1971). Presenza epifitica di Pseudomonas savastanoi (E. F. Smith) Stevens sull'olivo, in Puglia. Phytopathologia mediterranea 10, 130132.

Ercolani, G. L. (1973). Two hypotheses on the aetiology of response of plants to phytopathogenic bacteria. Journal of General Microbiology 75, 83-95.

ERcolanI, G. L. (1976). Bacteriological quality assessment of fresh marketed lettuce and fennels. Applied and Environmental Microbiology 31, 847852.

Ercolani, G. L. \& Crosse, J. E. (1966). The growth of Pseudomonas phaseolicola and related plant pathogens in vivo. Journal of General Microbiology 45, 429-439.

EwING, W. H. (1962). Enterobacteriaceae. Biochemical Methods for Group Differentiation. U.S. Department of Health, Education, and Welfare, Public Health Service Publication No. 734 (revised).

FoKKEMA, N. J. (1971). Influence of pollen on saprophytic and pathogenic fungi on rye leaves. In Ecology of Leaf Surface Micro-organisms, pp. 277282. Edited by T. F. Preece and C. H. Dickinson. London and New York: Academic Press.

Goodfellow, M., Austin, B. \& Dawson, D. (1976). Classification and identification of phylloplane bacteria using numerical taxonomy. In Microbiology of Aerial Plant Surfaces, pp. 275-292. Edited by C. H. Dickinson and T. F. Preece. London and New York: Academic Press.

Goro, M. (1972). The significance of the vegetation for the survival of plant pathogenic bacteria. In Proceedings of the Third International Conference on Plant Pathogenic Bacteria, pp. 39-53. Edited by H. P. Maas Geesteranus. Wageningen: Centre for Agricultural Publishing and Documentation.

Haynes, W. C. (1951). Pseudomonas aeruginosa - its 
characterization and identification. Journal of General Microbiology 5, 939-950.

JENSEN, V. (1971). The bacterial flora of beech leaves. In Ecology of Leaf Surface Micro-organisms, pp. 463-469. Edited by T. F. Preece and C. H. Dickinson. London and New York: Academic Press.

KLEMENT, Z. (1963). Rapid detection of the pathogenicity of phytopathogenic pseudomonads. Nature, London 199, 299-300.

Klincäre, A. A., Krëslina, D. J. \& Mishke, I. V. (1971). Composition and activity of the epiphytic microflora of some agricultural plants. In Ecology of Leaf Surface Micro-organisms, pp. 191-201. Edited by T. F. Preece and C. H. Dickinson. London and New York: Academic Press.

LEBEN, C. (1963). Multiplication of Xanthomonas vesicatoria on tomato seedlings. Phytopathology 53, 778-781.

LeBEN, C. (1965). Epiphytic microorganisms in relation to plant disease. Annual Review of Phytopathology 3, 209-230.

LEBEN, C. (1974). Survival of plant pathogenic bacteria. Ohio Agricultural Research and Development Center Special Circular 100.

Lelliott, R. A., Billing, E. \& Hayward, A. C. (1966). A determinative scheme for the fluorescent plant pathogenic pseudomonads. Journal of Applied Bacteriology 29, 470-489.

Liston, J., Wiebe, W. \& ColWell, R. R. (1963). Quantitative approach to the study of bacterial species. Journal of Bacteriology 85, 1061-1070.

Mundt, J. O., CogGin, J. H., JR \& Johnson, L. F. (1962). Growth of Streptococcus faecalis var. liquefaciens on plants. Applied Microbiology 10, 552-555.

Murata, N. \& StarR, M. P. (1974). Intrageneric clustering and divergence of Erwinia strains from plants and man in the light of deoxyribonucleic acid segmental homology. Canadian Journal of Microbiology 20, 1545-1565.

Oliver, J. D. \& Colwell, R. R. (1974). Computer program designed to follow fluctuations in microbial populations and its application in a study of Chesapeake Bay microflora. Applied Microbiology 28, 185-192.

Pederson, C.S. (1936). A study of the species Lactobacillus plantarum (Orla-Jensen) Bergey et al. Journal of Bacteriology 31, 217-224.

Pengra, R. M. \& Wilson, P. W. (1958). Physiology of nitrogen fixation by Aerobacter aerogenes. Journal of Bacteriology 75, 21-25.

Sands, D. C., Schroth, M. N. \& Hildebrand, D. C. (1970). Taxonomy of phytopathogenic pseudomonads. Journal of Bacteriology 101, 9-23.

Schuster, M. L. \& CoYNE, D. P. (1974). Survival mechanisms of phytopathogenic bacteria. Annual Review of Phytopathology 12, 199-221.

Skerman, V. B. D. (1967). A Guide to the Identification of the Genera of Bacteria, 2nd edn. Baltimore: Williams \& Wilkins.

SMITH, E. F. (1920). An Introduction to Bacterial Diseases of Plants. Philadelphia and London: W. B. Saunders.

SNeATH, P. H. A. (1956). Cultural and biochemical characteristics of the genus Chromobacterium. Journal of General Microbiology 15, 70-98.

SNEATH, P. H. A. (1957). The application of computers to taxonomy. Journal of General Microbiology 17, 201-226.

SNeath, P. H. A. (1972). Computer taxonomy. Methods in Microbiology 7A, 29-98.

Sneath, P. H. A. \& Johnson, R. (1972). The influence on numerical taxonomic similarities of errors in microbiological tests. Journal of General Microbiology 72, 377-392.

SokAL, R. R. \& Michener, C. D. (1958). A statistical method for evaluating systematic relationships. Kansas University Science Bulletin 38, 1409-1438.

Sokal, R. R. \& Sneath, P. H. A. (1963). Principles of Numerical Taxonomy. San Francisco: W. H. Freeman.

Stanier, R. Y., Palleroni, N. J. \& Doudoroff, M. (1966). The aerobic pseudomonads: a taxonomic study. Journal of General Microbiology 43, 159. 271.

Stirling, A. C. \& Whittenbury, R. (1963). Sources of the lactic acid bacteria occurring on silage. Journal of Applied Bacteriology 26, 86-90.

St John, R. T., ShaH, V. K. \& BRILL, W. J. (1974). Regulation of nitrogenase synthesis by oxygen in Klebsiella pneumoniae. Journal of Bacteriology 119, 266-269.

STout, J. D. (1960). Bacteria of soil and pasture leaves at Claudelands Showgrounds. New Zealand Journal of Agricultural Research 3, 413-430.

VAUGHN, R. H. (1954). Lactic acid fermentation of cucumbers, sauerkraut and olives. In Industrial Fermentations, vol. 2, pp. 417-478. Edited by L. A. Underkofler and R. J. Hickey. New York: Chemical Publishing Co.

Voznyakovskaya, Yu. M. \& Khudyakov, Ya. P. (1960). Species composition of the epiphytic microflora of living plants. Microbiology (translation of Mikrobiologiya) 29, 73-76.

WhitTenBuRY, R. (1965). The differentiation of Streptococcus faecalis and S. faecium. Journal of General Microbiology 38, 279-287.

Yoder, O. C. \& Whalen, M. L. (1975). Factors affecting post-harvest infection of stored cabbage tissue by Botrytis cinerea. Canadian Journal of Botany 53, 691-699. 